Научная статья

УДК 379.85

DOI https://doi.org/10.24866/VVSU/2073-3984/2021-4/050-071

\author{
А. Ю. Кононов ${ }^{1}$ \\ К. А. Мальцева ${ }^{2}$ \\ Владивостокский государственный университет экономики и сервиса \\ Владивосток. Россия
}

\title{
Военно-исторический туризм как перспективное направление молодежного туризма в Приморском крае
}

\begin{abstract}
Аннотация. Объектом исследования выступает военно-исторический туризм. Цель работы - оценить перспективы развития военно-исторического туризма как направление молодёжного туризма в Приморском крае. Для достижения цели были поставлены и решены определенные задачи. На первом этапе был систематизирован понятийный аппарат военно-исторического и молодежного туризма. На втором этапе была определена нормативно-правовая, методическая и ресурсная база военно-исторического и молодежного туризма; выявлены мотивационные факторы востребованности военноисторического туризма среди молодежи, а также было проанализировано предложение на рынке военно-исторического туризма на федеральном и региональном уровне. На заключительном этапе были систематизированы перспективы развития военноисторического туризма как вида молодежного туризма. Исследование теоретических аспектов проводилось с помощью таких методов научного познания, как метод сравнения, индукция и дедукция, методы актуализации, системного анализа, классификации, абстрагирования и конкретизации. Практическая значимость работы состоит в систематизации и актуализации теоретических подходов к анализу военно-исторического и молодежного туризма в новых условиях.
\end{abstract}

Ключевые слова: туризм, военно-исторический туризм, молодёжный туризм, региональный туристский продукт, Российская Федерация, Приморский край, Владивостокская крепость.

\section{A. Yu. Kononov}

\section{K.A. Maltseva}

Vladivostok State University of Economics and Service Vladivostok. Russia

\footnotetext{
${ }^{1}$ Кононов Артем Юрьевич - канд. экон. наук, доцент кафедры туризма и экологии. ORCID: https://orcid.org/0000-0003-1955-0910; e-mail: artem.kononov@ vvsu.ru

2 Мальцева Ксения Андреевна - бакалавр 2-го курса кафедры туризма и экологии. ORCID: https://orcid.org/0000-0003-4146-869X; e-mail: maltseva_ksenechka@autlook.com
} 
А.Ю. Кононов, К.А. Мальцева. Военно-исторический туризм как перспективное направление...

\title{
Military tourism as a promising direction of youth tourism in Primorsky Krai
}

\begin{abstract}
The object of the study is military tourism. The purpose of the work is to assess the prospects for the development of military tourism as a direction of youth tourism in Primorsky Krai. To achieve this goal, certain tasks were identified and solved. At the first stage, the conceptual frameworks of military and youth tourism were systematized. Then determined were the regulatory, methodological and resource bases of military tourism and youth tourism. The motivational factors of the demand for military tourism among young people were identified. The supply side of military tourism at the federal and regional levels was also analyzed. At the final stage, the pros-pects for the development of military tourism as a type of youth tourism were systematized. The study of theoretical aspects was carried out using such methods of scientific research as the method of comparison, induction and deduc-tion methods, methods of actualization, system analysis, classification, abstraction and concretization. The practical significance of the work consists in the systematization and actualization of theoretical approaches to the analysis of military-historical and youth tourism in new conditions.
\end{abstract}

Keywords: tourism; military history tourism; youth tourism; regional tourism product; Russian Federation; Primorsky Krai; Vladivostok fortress.

\section{Введение}

Молодёжный туризм («туризм лиц в возрасте от 18 до 35 лет» согласно определению, зафиксированному в «Стратегии развития туризма в Российской Федерации на период до 2035 года» [1]) - важный современный феномен.

На национальном уровне в современных условиях актуальность развития молодежного туризма была зафиксирована в Послании Президента Федеральному Собранию от 21 апреля 2021 года, в котором отмечена необходимость поощрять «молодёжь, которая проявила себя в олимпиадах, волонтёрских и творческих инициативах, проектах платформы «Россия - страна возможностей». Для таких ребят программа частичного возврата средств за туристическую путёвку будет действовать и в каникулярный период, в каникулы, в так называемый высокий сезон. До этого... таких решений не принимали» [2].

На мировом уровне Всемирная туристская организация (ЮНВТО) отмечает, что почти $20 \%$ туристов являются молодыми людьми [3]. Это особенно актуально в текущих условиях, так как молодёжная аудитория с меньшей вероятностью поддается влиянию экономических проблем, политических волнений или эпидемий [4].

В то же время действительная важность молодежного рынка выходит далеко за рамки статистических цифр: молодые люди признаются одной из основных сил, определяющих и непосредственно влияющих на развитие общественных перемен. Так, молодые люди рассматривают туризм как важную часть своей повседневной жизни, а не как непродолжительный уход от повседневности. В этих условиях они проводят больше времени в одной поездке, чаще путешествуют, 
более активно вовлекаются в широкий спектр деятельности, чаще возвращаются в ранее посещенные города. Такое восприятие имеет важные последствия для дестинаций, позволяет раскрыть значительный экономический потенциал молодежного туризма, сгладить эффект сезонности, построить более гибкий туристский рынок, развить новые виды туризма [4].

При этом по мере исследования молодежного туризма как комплексного понятия составляется представление о мотивациях, потребностях и целях молодых людей, к основным из которых, согласно исследованиям ЮНВТО, можно отнести обучение, возможность познакомиться с другими людьми и культурами и вовлечься в более широкий спектр деятельности, который позволяет определить источник саморазвития и самоидентификации [3]. В действительности молодые люди через путешествия стремятся взаимодействовать с сообществами и вносить в них изменения.

Стоит отметить, что одним из мотивов молодежного туризма часто становится поиск приключенческих событий, так как молодые люди - наиболее динамичная и активная часть общества, которая стремится к новаторским переменам и исследованию нового.

Именно поэтому молодых людей рационально вовлекать в военноисторический туризм, который способен удовлетворить их потребности в приключениях и стать фактором, раскрывающим их интересы в познании потенциально нового.

Предмет, источниковая база исследования, противоречия в имеющихся исследованиях и авторская позиция

Федеральный закон «Об основах туристской деятельности в Российской Федерации» определяет туристские ресурсы как «природные, исторические, социально-культурные объекты, включающие объекты туристского показа, а также иные объекты, способные удовлетворить духовные и иные потребности туристов, содействовать поддержанию их жизнедеятельности, восстановлению и развитию их физических сил» [5].

При этом с точки зрения классификации зонтичным термином для многих близких по природе и характеру видов туризма (исторического, религиозного, паломнического, этнического, этнографического, фольклорного, антропологического, археологического, событийного, художественного, музейного, архитектурного, замкового, дворцового, литературного, музыкального и многих других) является культурный (культурно-познавательный или познавательный) туризм в широком смысле. Это объясняется тем, что молодые люди «базируются на культуре», т.е. объединены общими интересами и мотивациями путешественников (познанием культуры «другого», поиском нового культурного опыта и межкультурных контактов), при этом используются общие культурно-исторические ресурсы [6].

В то же время ряд исследователей отдельно выделяет военно-исторический туризм (табл. 1) [7, 8]. 
А.Ю. Кононов, К.А. Мальцева. Военно-исторический туризм как перспективное направление...

Таблица 1

Подходы к определению понятия «военно-исторический туризм»

\begin{tabular}{|l|l|}
\hline \multicolumn{1}{|c|}{ Автор } & \multicolumn{1}{c|}{ Определение } \\
\hline И.Ю. Соломина & $\begin{array}{l}\text { Военно-исторический туризм - подвид культурно-исторического туризма, } \\
\text { который характеризуется интересом к военной истории, посещением па- } \\
\text { мятников героям и памятных мест, чтением тематических лекций по во- } \\
\text { енной истории }\end{array}$ \\
\hline $\begin{array}{l}\text { С.К. Волков, } \\
\text { О.В. Конина, } \\
\text { А. Аебелый }\end{array}$ & $\begin{array}{l}\text { Военно-исторический туризм как форма представления исторических } \\
\text { героических событий в виде событийных мероприятий (фестивалей, ре- } \\
\text { конструкций), туристских маршрутов по местам боевой славы; посещение } \\
\text { полей военных сражений, музейных объектов, действующих военных } \\
\text { объектов и полигонов, мест дислокации боевых транспортных средств; } \\
\text { участие в военно-спортивных мероприятиях }\end{array}$ \\
\hline Т.В. Гордиенко & $\begin{array}{l}\text { Вид туризма, связанный с использованием военной техники и ориентиро- } \\
\text { ванный на развитие культурно-познавательных и спортивно-туристских } \\
\text { программ }\end{array}$ \\
\hline Е.А. Титова & $\begin{array}{l}\text { Вид путешествия, в ходе которого турист знакомится с национальной и } \\
\text { местной культурой, связанной с военной историей }\end{array}$ \\
\hline Т.А. Колпащикова & $\begin{array}{l}\text { Военно-исторический туризм - комплексное явление, в котором сочетает- } \\
\text { ся выезд туриста с территории своего региона (страны) в другой регион } \\
\text { (страну) для ознакомления с культурой и её постижением, в результате } \\
\text { которого личность формирует культурную компетентность, самосознание } \\
\text { и культурное самоопределение в мировом пространстве }\end{array}$ \\
\hline Е.С. Голикова & $\begin{array}{l}\text { Область патриотического туризма, которая охватывает собою посещение } \\
\text { мест военных сражений, памятных мемориалов, музеев истории и краеве- } \\
\text { дения, служащих средством примирения и упрочения единства и дружбы } \\
\text { народов через патриотическое воспитание молодых граждан }\end{array}$ \\
\hline
\end{tabular}

Можно отметить, что в целом под военно-историческим туризмом понимаются следующие формы презентации исторических событий:

- проведение фестивалей, реконструкций;

- туристские маршруты по местам боевой славы;

- посещение мест военных сражений, предметов и экспонатов военных музеев, активных объектов и полигонов; мест дислокации боевых машин;

- участие в военно-спортивных мероприятиях.

При этом Б. М. Шаваринский в контексте молодежного туризма указывал, что в текущем времени в патриотическом воспитании все больше лидирующие позиции занимают направления духовно-нравственного, историко- и культурнопатриотического воздействия на молодёжь, что способствует обогащению содержания как самого воспитания, так и повышению его возможностей в формировании ценностей у различных категорий молодёжи. (При этом стоит отметить, что военно-патриотическое воспитание уходит на второстепенные позиции.) [9].

В.И. Левин отмечает, что военно-исторический туризм является одним из важнейших способов патриотического воспитания и выступает мощным стиму- 
лом позитивного развития личности, воспитания российских граждан и в особенности молодого поколения [10].

Я. В. Мещерякова акцентирует внимание на том, что понимание совершенного и его последствий позволяет сформировать устойчивое мнение молодого поколения о недопущении подобного в будущем... (о возможности развития дружественных связей в рамках культурного, социально-экономического, научно-исследовательского взаимодействия) [11].

В то же время вопрос мотивационной составляющей вовлеченности в военно-исторический туризм молодежи в научных трудах по-прежнему представлен в значительной степени фрагментарно и требует дальнейшей систематизации.

Углубления требует также анализ условий и тенденций развития военноисторического туризма в Приморском крае.

Целью исследования является определение перспектив развития военноисторического туризма как направления молодёжного туризма в Приморском крае.

Для выполнения поставленных целей необходимо конкретизировать и выполнить следующие задачи:

- систематизировать понятийный аппарат военно-исторического и молодежного туризма;

- определить нормативно-правовую, методическую и ресурсную базы военно-исторического и молодежного туризма;

- выявить мотивационные факторы востребованности военно-исторического туризма среди молодежи;

- проанализировать предложение на рынке военно-исторического туризма на федеральном и региональном уровне;

- систематизировать перспективы развития военно-исторического туризма как вида молодежного туризма.

Методы исследования. Исследование проводилось с помощью таких методов научного познания, как метод сравнения, индукция и дедукция, методы актуализации, системного анализа, классификации, абстрагирования и конкретизации.

\section{Основная часть}

Военно-исторический туризм - важное направление государственной политики в сфере туризма. Можно отметить, что уже в Федеральной целевой программе «Развитие внутреннего и въездного туризма в Российской Федерации (2011-2018)» фиксировался тот факт, что «важнейшим конкурентным преимуществом туристской отрасли Российской Федерации является историкокультурное наследие. На поездки с культурно-познавательными целями приходится около $20 \%$ внутреннего туристского потока» [12]. При этом значительный потенциал запуска деловой активности в данном контексте демонстрирует опыт формирования Куликовского кластера, предполагающего создание новых музеев, в том числе под открытым небом, строительство межрегионального центра фондохранилища, молодежного и архивного центра, строительство и реконст- 
А.Ю. Кононов, К.А. Мальцева. Военно-исторический туризм как перспективное направление...

рукцию дорог, очистку рек, реконструкцию инженерных сетей, благоустройство территорий.

Вместе с тем при формирования итогового продукта в военно-историческом туризме можно выделить уровни, представленные на рис. 1 [13].

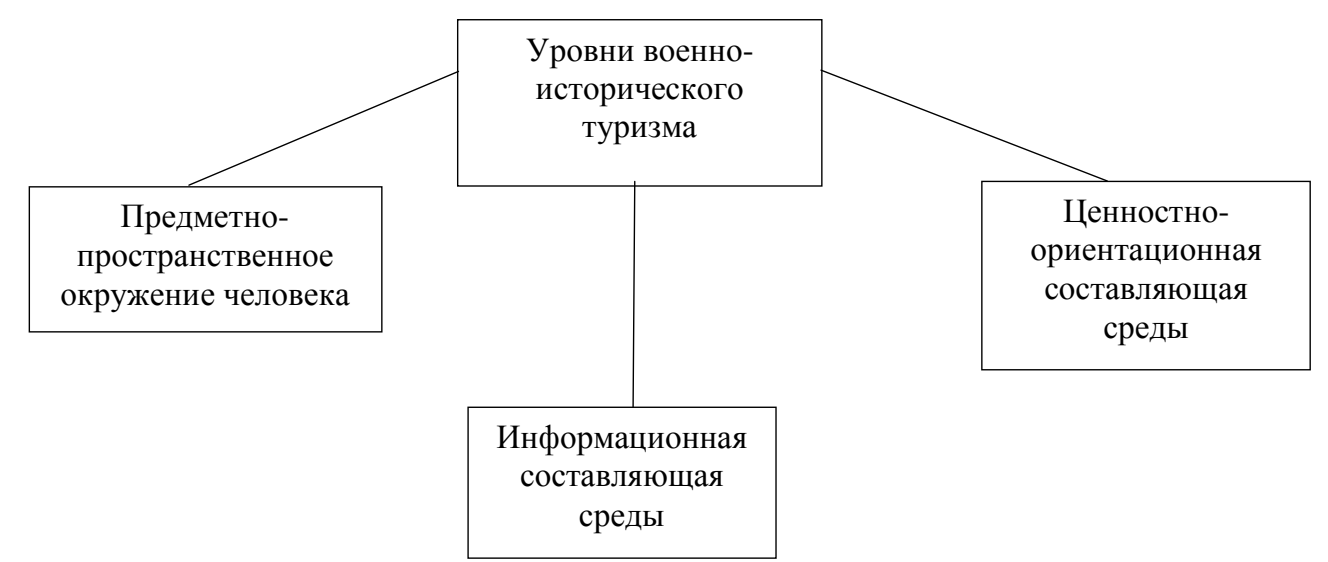

Рис. 1. Уровни военно-исторического туризма

C точки зрения предметно-пространственного окружения военноисторического туризма необходимо отметить естественную неравномерность географического распределения ресурсов, зафиксированную, в частности, в атласе военно-исторических маршрутов, представленном в совместном проекте Российского военно-исторического общества и Федерального агентства по туризму (рис. 2) [14].

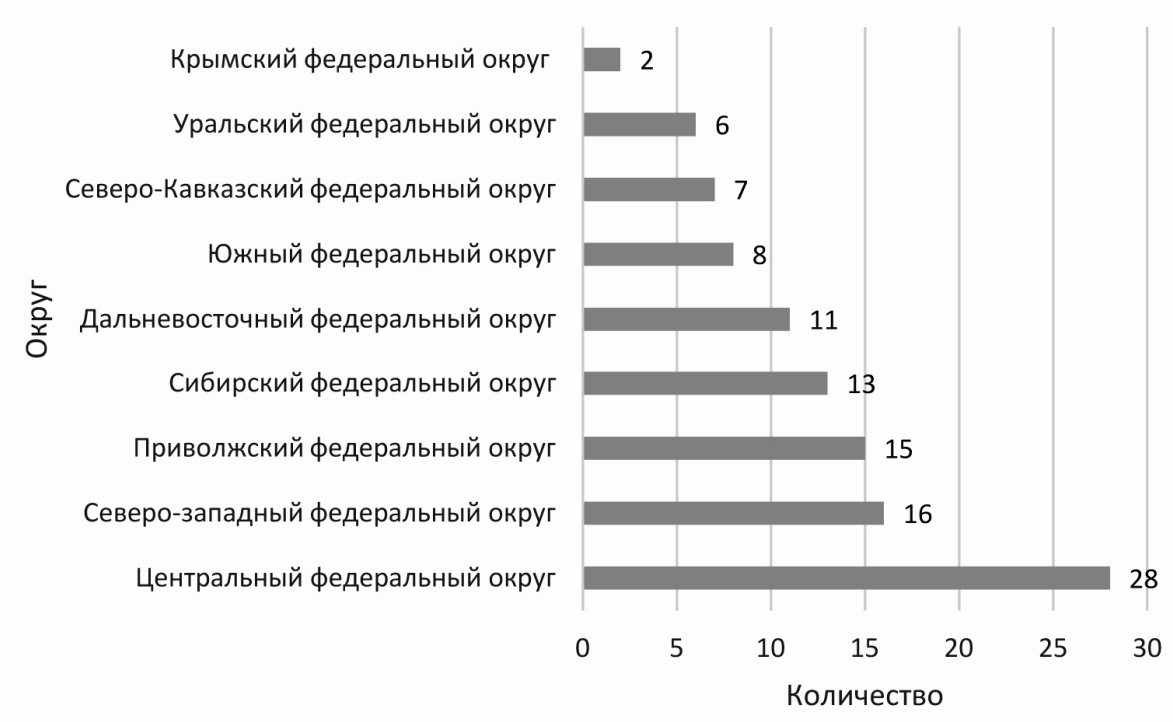

Рис. 2. Распределение военно-исторических маршрутов 
Схожая конъюнктура сформировалась и на рынке реализуемых военноисторических туров. Так, в западных регионах Российской Федерации успешно представлены военно-исторические туры (табл. 2) [15].

Таблииа 2

\section{Военно-исторические туры}

\begin{tabular}{|c|c|c|c|c|}
\hline Название & Дни & Города & $\begin{array}{l}\text { Стоимость, } \\
\text { руб. }\end{array}$ & Объекты показа \\
\hline $\begin{array}{l}\text { Вспоминая } \\
\text { о подвигах } \\
\text { Великой } \\
\text { войны }\end{array}$ & 3 & $\begin{array}{l}\text { Белгород, } \\
\text { Прохоровка }\end{array}$ & 12900 & $\begin{array}{l}\text { Музей-мемориал «В честь героев Курской } \\
\text { битвы», Прохоровское поле, музей броне- } \\
\text { танковой техники, музей «Битва за оружие } \\
\text { Великой Победы», храм во имя святых } \\
\text { Петра и Павла, диорама «Огненная дуга» }\end{array}$ \\
\hline $\begin{array}{l}\text { День Воен- } \\
\text { но- } \\
\text { Морского } \\
\text { Флота }\end{array}$ & 3 & $\begin{array}{l}\text { Санкт- } \\
\text { Петербург }\end{array}$ & 6550 & $\begin{array}{l}\text { Петропавловская крепость, Петропавлов- } \\
\text { ский собор, тюрьма Трубецкого бастиона, } \\
\text { Кронштадт, форт «Император Александр I» }\end{array}$ \\
\hline $\begin{array}{l}\text { День Побе- } \\
\text { ды }\end{array}$ & 3 & $\begin{array}{l}\text { Волгоград, } \\
\text { Самара }\end{array}$ & 8680 & $\begin{array}{l}\text { Памятник - ансамбль на Мамаевом Курга- } \\
\text { не, историко-мемориальный комплекс } \\
\text { «Героям Сталинградской битвы», Аллея } \\
\text { героев, площадь Павших Борцов, дом } \\
\text { Павлова, мельница Грудинина, экспозиция } \\
\text { «Память Сталинграда», музей-панорама } \\
\text { «Салинградская битва» }\end{array}$ \\
\hline $\begin{array}{l}\text { Путь воин- } \\
\text { ской славы }\end{array}$ & 3 & $\begin{array}{l}\text { Бородино, } \\
\text { Доронино, } \\
\text { Смоленск, } \\
\text { Талашкино, } \\
\text { Вязьма }\end{array}$ & 11342 & $\begin{array}{l}\text { Бородинский музей-заповедник, Спасо- } \\
\text { Бородинский монастырь, военно- } \\
\text { историческое поселение «Доронино», Та- } \\
\text { лашкино, Смоленская крепостная стена, } \\
\text { Соборный холм, Главный храм Воору- } \\
\text { женных Сил РФ }\end{array}$ \\
\hline $\begin{array}{l}\text { Обереги } \\
\text { земли рус- } \\
\text { ской }\end{array}$ & 3 & $\begin{array}{l}\text { Епифань, } \\
\text { Себино, } \\
\text { Куликово } \\
\text { поле, Венев }\end{array}$ & 7780 & $\begin{array}{l}\text { Музей Куликовской битвы, историко- } \\
\text { этнографический музей Епифань, экспо- } \\
\text { зиция «Сказание о Мамаевом побоище», } \\
\text { музейно-мемориальный комплекс «Мона- } \\
\text { стырщина» }\end{array}$ \\
\hline $\begin{array}{l}\text { Ржевский } \\
\text { рубеж }\end{array}$ & 2 & Тверь, Ржев & 8900 & $\begin{array}{l}\text { Казанский женский монастырь, Старица, } \\
\text { мемориал - монумент Советскому солдату }\end{array}$ \\
\hline $\begin{array}{l}\text { Дороги } \\
\text { славы }\end{array}$ & 5 & $\begin{array}{l}\text { Санкт- } \\
\text { Петербург }\end{array}$ & 10250 & $\begin{array}{l}\text { Царское село, Эрмитаж, Пискаревское } \\
\text { мемориальное кладбище, экспозиция в } \\
\text { особняке Румянцева, Кронштадт, Крон- } \\
\text { штадтский морской музей }\end{array}$ \\
\hline Ладога Фест & 4 & $\begin{array}{l}\text { Старая } \\
\text { Ладога }\end{array}$ & 10500 & $\begin{array}{l}\text { Крепостной комплекс, музей Воротная } \\
\text { башня, археологическая экспозиция, по- } \\
\text { сещение Никольского монастыря, истори- } \\
\text { ческая реконструкция в Старой Ладоге }\end{array}$ \\
\hline
\end{tabular}


А.Ю. Кононов, К.А. Мальцева. Военно-исторический туризм как перспективное направление...

Как видно из таблицы, средняя продолжительность тура составляет 3 дня, средняя стоимость - 9613 рублей, что является доступным для молодежи как целевого сегмента. Объекты туристского показа включают культурноисторические ресурсы, за которыми закреплена определённая глава военной истории и боевой славы. К вышеупомянутым ресурсам можно отнести такие объекты, как памятники, музеи военной истории, места сражений, а также оборонительные комплексы, которые чаще всего представлены крепостями.

В контексте ценностно-ориентационной составляющей среды можно отметить, что военно-исторический туризм реализует в обществе определённые установленные роли, которые могут быть подробно конкретизированы характерными функциями. В целом эти функции можно разделить на две крупные группы:

1) культурно-исторические;

2) воспитательные.

Однако если рассматривать данные функции детальнее, то можно выделить такие, как:

1) патриотическое воспитание граждан;

2) сохранение исторической правды, памяти и ценностей общества;

3) формирование целостного представления о военном потенциале государства;

4) осуществление передачи и обмена знаниями, опытом прошлых эпох для их сохранения и трансляции в будущем.

В этом контексте в Концепции федеральной целевой программы «Развитие внутреннего и въездного туризма в Российской Федерации (2019-2025)» отмечается, что «мероприятия программы будут способствовать реализации задач концепции долгосрочного социально-экономического развития Российской Федерации в части молодёжной политики, в том числе создадут условия для стимулирования интереса молодёжи к историческому и культурному наследию России, защите окружающей среды, для межрегионального молодёжного обмена путем развития системы внутреннего туризма как средства гражданского образования и патриотического воспитания молодёжи» [16].

Военно-исторический туризм - важное направление молодежного туризма, которое при этом может быть интересно молодёжи за счёт возможности удовлетворения их потребностей в экспериментальных приключенческих поездках и разнообразном поиске новых динамичных событий, так как ресурсная база военно-исторического туризма напрямую позволяет молодым людям интерактивно взаимодействовать с наследием и воспринимать путешествия не как временную смену условий локации, а как неотъемлемую часть повседневной жизни, через которую познанием можно выстроить собственный образ мира.

В Приморском крае военно-исторический туризм рассматривается как одно из важных направлений развития с точки зрения формирования регионального туристского продукта. Интерес здесь можно объяснить рядом факторов, представленных на рис. 3. 


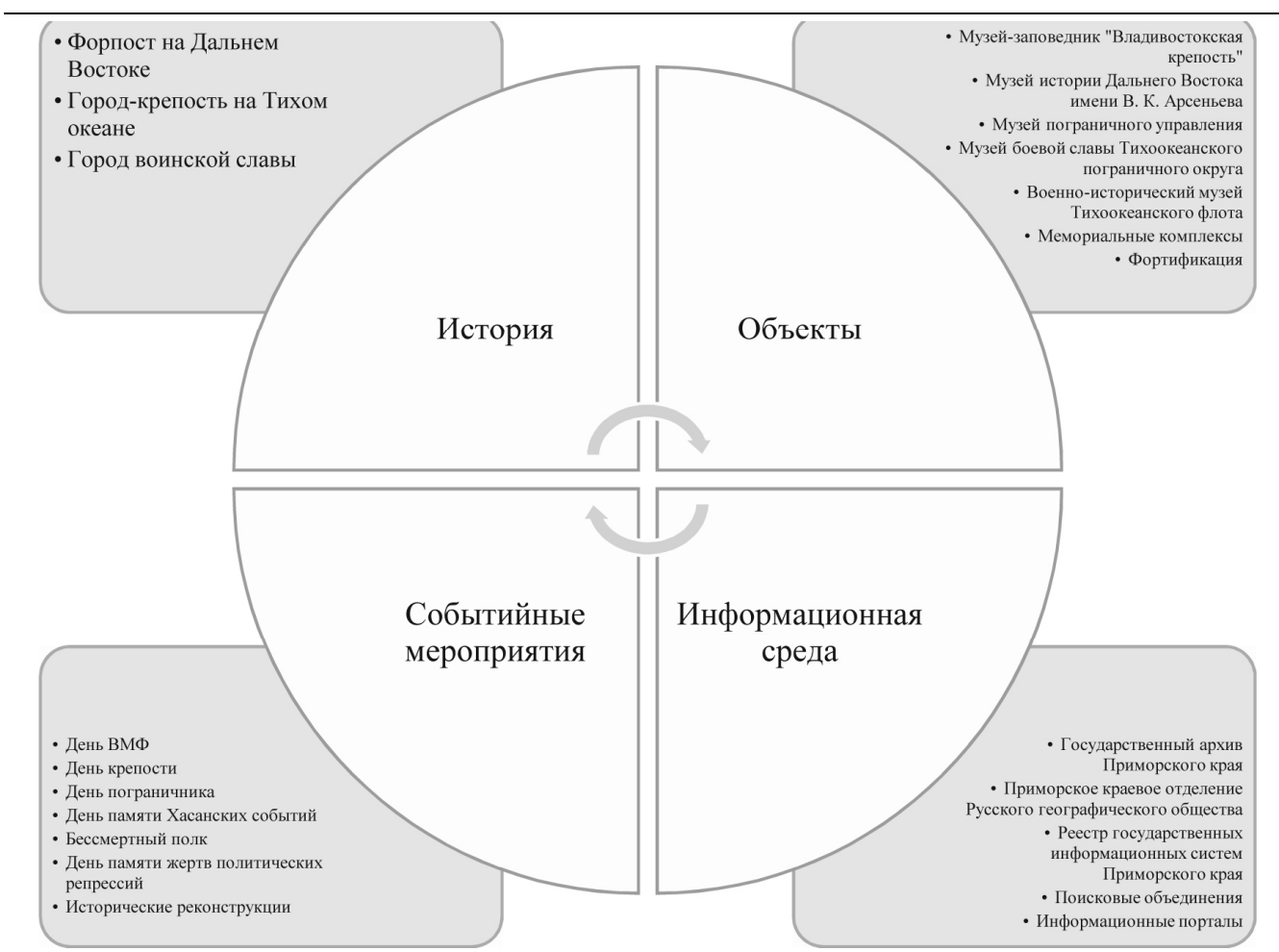

Рис. 3. Факторы развития военно-исторического туризма в Приморском крае

В результате из всех маршрутов Приморского края, перечисленных на сайте Туристско-информационного центра Приморского края, 23 маршрута $(7,8 \%)$ разделяют тему военного наследия [17]. Большая часть маршрутов проходит по территории Владивостока (14 маршрутов, или $61 \%$ ), остальные покрывают Хасанский, Шкотовский, Лазовский, Артемовский, Уссурийский, Находкинский и Партизанский районы.

При этом самыми популярными объектами являются средневековые поселения (в Красном Яру, Екатериновке) - 6 маршрутов (26\%); три маршрута $(13 \%)$ включают посещение парка «Изумрудная долина» в Уссурийском городском округе, в то время как $52 \%$ маршрутов включает объекты Владивостокской крепости [18].

Владивостокская крепость - это особый фортификационный объект, который представляет собой комплекс долговременных оборонительных сооружений, построенных в конце XIX - начале XX века во Владивостоке и в его близлежащих окрестностях [19].

По своим особенностям Владивостокская крепость - объект уникальный по многим параметрам. Прежде всего, оборонительное сооружение являлось самым мощным и передовым фортификационным комплексом не только в пределах нашей страны, на то время ещё Российской Империи, но и в масштабах всего мира. Владивостокская крепость - это не одно конкретное сооружение. Это в 
А.Ю. Кононов, К.А. Мальцева. Военно-исторический туризм как перспективное направление...

первую очередь огромный военно-исторический комплекс, включающий в себя, согласно данным музея-заповедника «Владивостокская крепость», более восьмисот объектов, среди которых выделяют оборонительные сооружения (форты, опорные пункты, редуты, береговые и сухопутные батареи, пороховые погреба, противодесантные капониры и полукапониры), инфраструктурные объекты (управления, казармы, флигели, склады, хранилища продуктов, искровые радиостанции и пр.), коммуникации (дороги, мосты, сеть канатных дорог, причалы) $[20,21]$.

Ещё одной отличительной чертой Владивостокской крепости является то, она имеет закольцованное расположение, при этом разделяется на три линии обороны - северную, главную и южную. Будучи крепостью, которую возводили с учётом опыта падения Порт-Артура и итогов русско-японской войны (19041905), она строилась с опорой на все достижения фортификационной науки того времени. Крепостные сооружения прекрасно вписывали в пересечённый рельеф местности, проектируя их на господствующих высотах ландшафта, которыми являлись Седанкинский хребет, наивысшие точки самого города, главные вершины и побережье острова Русский. Стоит отметить, что во многом это значительно увеличивало боевые возможности сооружений. Строительство крепости шло в труднодоступной горнолесной местности, изрезанной глубокими речными долинами, что в большинстве определяло значительные выгоды для сухопутной обороны с широтных хребтов [22].

В целом строительство Владивостокской крепости является одной из интереснейших страниц истории фортификационного дела, влияние которого распространялось не только на Российскую Империю, но и на мир в целом, так как крепость показывает удивительный пример того, что оборонительный комплекс мог удерживать безопасность не только сухопутных рубежей, но и морских. В данном случае особенности существования оригинальной русской фортификационной школы не подлежат сомнению. Фортификационные условия Владивостокской крепости оказывали особое влияние на реализацию главенствующей цели любого оборонительного комплекса - наименьшими силами сопротивляться как можно дольше.

Этапы строительства Владивостокской крепости во многом определяли внешнеполитическая и военно-стратегическая ситуации как в регионе, так и в мире, которые менялись с поразительной быстротой в конце XIX - начале $\mathrm{XX}$ века. Ход истории существенно повлиял на то, что Владивостокская крепость стала наиболее динамично развивающимся фортификационным сооружением и в то же время замкнула собой ветвь инженерной мысли, став последней крепостью Российской Империи [20].

В современной действительности можно выделить шесть основных этапов возведения Владивостокской крепости:

1) 1860-1899 гг. - основание поста Владивосток и создание Владивостокской крепости;

2) 1899-1905 гг. - строительство второй, главной, линии обороны крепости, выпавшее на время русско-японской войны (1904-1905); 
3) 1905-1909 гг. - Владивостокская крепость в период первой русской революции (1905-1907) и дискуссии о целесообразности дальнейшего укрепления Владивостока;

4) 1910-1914 гг. - Владивостокская крепость накануне Первой мировой войны. Проектирование и строительство новой главной линии сухопутной обороны крепости и её берегового фронта (форты проекта 1910 года);

5) 1914-1917 гг. - Владивостокская крепость в период Первой мировой войны. Работа «на передовой линии тыла»;

6) 1917-1923 гг. - окончательное прекращение работ на крепости. Соглашение о демилитаризации и окончательное упразднение Владивостокской крепости [23].

1914 год стал переломным в строительстве - начало Первой мировой войны не прошло бесследно для Владивостока: поставки цемента из Новороссийска, осуществляемые морскими путями, были резко прекращены в силу того, что Турция закрыла черноморские проливы Босфор и Дарданеллы для российских судов.

Первое время темпы строительства удавалось сохранить, поскольку цемент, оставшийся после возведения других объектов крепости, представлял собой довольно масштабные запасы. Однако с 1915 года, по мере того как война затягивалась, ухудшая общемировую ситуацию, дальнейшее строительство оказалось под большой угрозой.

К концу 1916 года были достроены на две трети 11 фортов главной линии обороны; на многих объектах не успели построить лишь горжевые казармы. Помимо фортов практически было закончено строительство дорог, двух опорных пунктов, пяти береговых батарей долговременного типа и восьми групп тоннельных пороховых погребов.

1923 год стал роковым для Владивостокской крепости: соглашение между Японией и Дальневосточной республикой о демилитаризации навсегда завершило военную историю объекта. Оставшиеся сооружения были демонтированы, штабы и управления расформированы, фортификационные объекты остались заброшены.

Но, несмотря на внутренние социальные и экономические противоречия страны, качество и прочность возведённых сооружений и их последующая модернизация позволили сохранить важное значение крепости в течение нескольких десятилетий. В прошлом веке пехотные форты и ряд береговых батарей во многом реализовали важную роль в обеспечении безопасности тихоокеанских границ, предупредив не одно вторжение противника, но так и не сделав ни одного боевого выстрела.

Владивостокская крепость строилась в условиях быстрорастущих армий и модификации вооружений. История сложилась так, что строительство других крепостей запоздало к началу Первой мировой войны, а к её концу они остались за пределами государства. Создание фортов проекта 1910 года явилось заключительным этапом развития фортификации в мире. Именно владивостокские пехотные форты стали наивысшей ступенью развития форта как типа опорного 
А.Ю. Кононов, К.А. Мальцева. Военно-исторический туризм как перспективное направление...

пункта, несмотря на то, что Первая мировая война внесла свои коррективы в развитие долговременной фортификации. Владивостокская крепость была настолько прогрессивной для своего времени, что даже годы спустя она продолжала служить примером для подражания - образцом создания опорного пункта будущего, несмотря на значительную степень модернизации и изменения фортификационных стандартов [20].

Как было сказано ранее, самые большие и мощные объекты Владивостокской крепости построены в 1906-1918 годах. В этот период было возведено 11 самых масштабных фортов, которые имеют обширные наземные площади и сложные по устройству подземные части. Из них 7 фортов выстроены северной линией обороны на материке от Уссурийского до Амурского залива - территориально от бухты Щитовой до Зари; остальные 4 форта занимают южный рубеж острова Русский [21]. Описания некоторых фортов, доступных для туристского показа, представлены в табл. 3 [24].

Таблица 3

\section{Описание фортификационных сооружений Владивостокской крепости}

\begin{tabular}{|c|c|c|c|c|c|c|}
\hline Объект & Номер в реестре & Полный адрес & $\begin{array}{c}\text { Категория } \\
\text { историко- } \\
\text { культурно- } \\
\text { го насле- } \\
\text { дия }\end{array}$ & $\begin{array}{l}\text { Вид } \\
\text { объ- } \\
\text { екта }\end{array}$ & $\begin{array}{c}\text { Годы } \\
\text { строи- } \\
\text { тель- } \\
\text { ства }\end{array}$ & Вооружение \\
\hline $\begin{array}{l}\text { Форт } \\
\text { Поспелова }\end{array}$ & 251710114500616 & $\begin{array}{l}\text { Приморский } \\
\text { край, г. Владиво- } \\
\text { сток, о. Русский, } \\
\text { п-ов Сапёрный, } \\
\text { гора Поспелова } \\
\text { (высота 139,1), } \\
\text { вершина, склоны } \\
\text { горы }\end{array}$ & 1 & 1 & $\begin{array}{l}1899- \\
1904\end{array}$ & $\begin{array}{l}\text { Форт был } \\
\text { рассчитан на } \\
\text { десять 9- } \\
\text { фунтовых } \\
\text { (107-мм) } \\
\text { пушек и два } \\
\text { пулемёта на } \\
\text { крепостных } \\
\text { станках }\end{array}$ \\
\hline Форт № 3 & 251510114500016 & $\begin{array}{l}\text { Приморский } \\
\text { край, г. Владиво- } \\
\text { сток, р. Седанка, } \\
\text { южный борт } \\
\text { долины реки } \\
\text { (высота 423,3), } \\
\text { вершина, склоны } \\
\text { высоты }\end{array}$ & 1 & 1 & $\begin{array}{l}1910- \\
1917\end{array}$ & $\begin{array}{l}\text { Рассчитан на } \\
\text { две роты } \\
\text { пехоты, две } \\
\text { 3-дюймовые } \\
\text { скорострель- } \\
\text { ные пушки, } \\
\text { десять 57-мм } \\
\text { скорострель- } \\
\text { ных пушек, } \\
\text { четыре } \\
\text { 3-дюймовые } \\
\text { противо- } \\
\text { штурмовые } \\
\text { пушки и } \\
\text { восемь пуле- } \\
\text { мётов }\end{array}$ \\
\hline
\end{tabular}


Окончание табл. 3

\begin{tabular}{|c|c|c|c|c|c|c|}
\hline Объект & Номер в реестре & Полный адрес & $\begin{array}{c}\text { Категория } \\
\text { историко- } \\
\text { культурно- } \\
\text { го насле- } \\
\text { дия }\end{array}$ & $\begin{array}{l}\text { Вид } \\
\text { объ- } \\
\text { екта }\end{array}$ & $\begin{array}{c}\text { Годы } \\
\text { строи- } \\
\text { тель- } \\
\text { ства }\end{array}$ & Вооружение \\
\hline Форт № 4 & 251710114500296 & $\begin{array}{l}\text { Приморский } \\
\text { край, г. Владиво- } \\
\text { сток, р. Седанка, } \\
\text { южный борт } \\
\text { долины реки } \\
\text { (высота } 428,3) \text {, } \\
\text { вершина, склоны } \\
\text { высоты }\end{array}$ & 1 & 1 & $\begin{array}{l}1899- \\
1914\end{array}$ & $\begin{array}{l}\text { Рассчитан на } \\
\text { роту пехоты, } \\
\text { четыре про- } \\
\text { тивоштурмо- } \\
\text { вые пушки, } \\
\text { четыре } \\
\text { 3-дюймовые } \\
\text { скорострель- } \\
\text { ные пушки, } \\
\text { пулемёт и } \\
\text { тринадцать } \\
\text { 57-мм скоро- } \\
\text { стрельных } \\
\text { пушек }\end{array}$ \\
\hline Форт № 11 & 251510114500626 & $\begin{array}{l}\text { Приморский } \\
\text { край, г. Владиво- } \\
\text { сток, о. Русский, } \\
\text { мыс Тобизина } \\
\text { (высота } 105,8 \text { в } \\
1,2 \text { км севернее } \\
\text { основания мыса), } \\
\text { вершина, склоны } \\
\text { высоты }\end{array}$ & 1 & 1 & $\begin{array}{l}1910- \\
1917\end{array}$ & $\begin{array}{l}\text { Рассчитан на } \\
\text { роту пехоты, } \\
\text { десять } \\
\text { 3-дюймовых } \\
\text { скорострель- } \\
\text { ных пушек и } \\
\text { восемь } \\
\text { 3-дюймовых } \\
\text { противо- } \\
\text { штурмовых } \\
\text { пушек }\end{array}$ \\
\hline
\end{tabular}

Стоит отметить, что под категорией историко-культурного наследия понимается следующее значение объектов: объекты культурного наследия федерального значения (1-я категория), объекты культурного наследия регионального значения (2-я категория), объекты культурного наследия местного (муниципального) значения (3-я категория). Под видом объекта понимается его принадлежность к группе - памятники (1-й вид), ансамбли (2-й вид), достопримечательные места (3-й вид) [25].

При этом для понимания состояния объектов в ходе исследования был составлен отдельный реестр.

В отношении фортов можно отметить, что ряд объектов находится в процессе передачи в управление музея-заповедника «Владивостокская крепость» и на них можно попасть в составе экскурсий, устраиваемых музеем-заповедником (например, форт № 1).

Некоторые объекты представляют определённую опасность (например, на форте № 2 опасность представляют бетонный резервуар в районе кофра, люки колодцев для запаса воды, спуски во рвах, отверстия в полах боевых казематов кофров, заледеневающий зимой тыльный проход. В двойном кофре есть опас62 
ность падения с высоты, отсутствует лестница сразу при входе. Форт № 9 - неограждённый участок сразу после входа в подбрустверную галерею с правого фланга).

Некоторые объекты пострадали в результате строительства объектов саммита АТЭС 2012 года (форт № 3).

Частично на объектах территория недоступна (например, форт Русских, форты № 2, 6, форт Муравьева-Амурского).

Некоторые объекты повреждены взрывами (форт № 5) или частично разрушены (форты № 6, 11, 12, форт Линевича), заброшены (форт Суворова).

Стоит отметить, что в реестр также включены береговые батареи, полукапониры, капониры.

В современной действительности своё оборонительное значение, заложенное военными инженерами, крепость утратила несмотря на то, что она считалась действующим военным комплексом порядка 60 лет. Однако Владивостокская крепость очень быстро из оборонительного комплекса превратилась в весомую часть военно-исторического потенциала страны, получив статус объекта культурного наследия народов РФ федерального значения.

Стоит отметить, что Владивостокская крепость уже является весьма популярным и известным военно-историческим объектом Приморского края, о чем может свидетельствовать разнообразное количество предложений, охватывающее практически весь комплекс крепости (табл. 4).

Таблища 4

Основные экскурсии по Владивостокской крепости

\begin{tabular}{|l|l|l|c|l|}
\hline \multicolumn{1}{|c|}{ Организатор } & \multicolumn{1}{|c|}{ Экскурсия } & \multicolumn{1}{|c|}{ Объект } & $\begin{array}{c}\text { Длитель- } \\
\text { ность }\end{array}$ & $\begin{array}{c}\text { Стоимость } \\
\text { (на } \\
01.04 .2021)\end{array}$ \\
\hline $\begin{array}{l}\text { Владивостокский } \\
\text { диггер-клуб }\end{array}$ & $\begin{array}{l}\text { Подземная пешеход- } \\
\text { ная экскурсия «Тай- } \\
\text { ные тропы Партии» }\end{array}$ & $\begin{array}{l}\text { Подземный спец. } \\
\text { объект № 1 МПВО г. } \\
\text { Владивостока и убе- } \\
\text { жище УНКВД }\end{array}$ & 2 ч & $\begin{array}{l}1050 \\
\text { руб./чел. }\end{array}$ \\
\hline $\begin{array}{l}\text { Владивостокский } \\
\text { диггер-клуб }\end{array}$ & $\begin{array}{l}\text { Владивостокская кре- } \\
\text { пость: форт № 7 } \\
\text { им. Цесаревича } \\
\text { Алексея }\end{array}$ & $\begin{array}{l}\text { Форт № 7 им. Цеса- } \\
\text { ревича Алексея }\end{array}$ & 2,5 ч & $\begin{array}{l}1250 \\
\text { руб./чел. }\end{array}$ \\
\hline $\begin{array}{l}\text { Владивостокский } \\
\text { диггер-клуб }\end{array}$ & $\begin{array}{l}\text { Остров Русский: два } \\
\text { форта - два проекта }\end{array}$ & $\begin{array}{l}\text { Форт Поспелова и } \\
\text { форт № 12 }\end{array}$ & $\begin{array}{l}1350 \\
\text { руб./чел. }\end{array}$ \\
\hline $\begin{array}{l}\text { Владивостокский } \\
\text { диггер-клуб }\end{array}$ & $\begin{array}{l}\text { Владивостокская кре- } \\
\text { пость: форт № 3 } \\
\text { им. Императрицы } \\
\text { Екатерины Великой }\end{array}$ & $\begin{array}{l}\text { Форт № 3 им. Импе- } \\
\text { ратрицы Екатерины } \\
\text { Великой }\end{array}$ & 5 ч & $\begin{array}{l}1300 \\
\text { руб./чел. }\end{array}$ \\
\hline
\end{tabular}


Окончание табл. 4

\begin{tabular}{|c|c|c|c|c|}
\hline Организатор & Экскурсия & Объект & $\begin{array}{c}\text { Длитель- } \\
\text { ность }\end{array}$ & $\begin{array}{l}\text { Стоимость } \\
\quad \text { на } \\
01.04 .2021)\end{array}$ \\
\hline $\begin{array}{l}\text { Владивостокский } \\
\text { диггер-клуб }\end{array}$ & $\begin{array}{l}\text { Форт № } 1 \text { Влад. кре- } \\
\text { пости с подземельями }\end{array}$ & $\begin{array}{l}\text { Форт № } 1 \text { им. Ми- } \\
\text { хаила Фёдоровича }\end{array}$ & 6 ч & $\begin{array}{l}2200 \\
\text { руб./чел. }\end{array}$ \\
\hline $\begin{array}{l}\text { Владивостокский } \\
\text { диггер-клуб }\end{array}$ & $\begin{array}{l}\text { Владивостокская кре- } \\
\text { пость: форт № } 4\end{array}$ & $\begin{array}{l}\text { Форт № } 4 \text { им. Импе- } \\
\text { ратора Александра I }\end{array}$ & 5 ч & $\begin{array}{l}1300 \\
\text { руб./чел. }\end{array}$ \\
\hline $\begin{array}{l}\text { Владивостокский } \\
\text { диггер-клуб }\end{array}$ & $\begin{array}{l}\text { Южный отдел оборо- } \\
\text { ны - о. Русский: форт } \\
\text { № } 11 \text { Влад. крепости } \\
\text { плюс музей }\end{array}$ & $\begin{array}{l}\text { Форт № } 11 \text { им. Кня- } \\
\text { зя Святослава Иго- } \\
\text { ревича и пороховой } \\
\text { погреб № } 13\end{array}$ & 5 ч & $\begin{array}{l}1400 \\
\text { руб./чел }\end{array}$ \\
\hline $\begin{array}{l}\text { Владивостокский } \\
\text { диггер-клуб }\end{array}$ & $\begin{array}{l}\text { Остров Русский: форт } \\
\text { № } 9 \text { Влад. крепости и } \\
\text { береговая батарея № } \\
982\end{array}$ & $\begin{array}{l}\text { Форт № } 9 \text { имени } \\
\text { Князя Рюрика, бере- } \\
\text { говая батарея № } 982\end{array}$ & 6 ч & $\begin{array}{l}1700 \\
\text { руб./чел. }\end{array}$ \\
\hline $\begin{array}{l}\text { Музей- } \\
\text { заповедник } \\
\text { «Владивосток- } \\
\text { ская крепость» }\end{array}$ & $\begin{array}{l}\text { Пешеходная экскур- } \\
\text { сия «Форт № 1» }\end{array}$ & $\begin{array}{l}\text { Форт № } 1 \text { им. Ми- } \\
\text { хаила Фёдоровича }\end{array}$ & 4 ч & $\begin{array}{l}\text { Полный - } \\
700 \text { руб., } \\
\text { льготный - } \\
500 \text { руб. }\end{array}$ \\
\hline $\begin{array}{l}\text { Музей- } \\
\text { заповедник } \\
\text { «Владивосток- } \\
\text { ская крепость» }\end{array}$ & $\begin{array}{l}\text { Игровая экскурсия по } \\
\text { форту Поспелова }\end{array}$ & Форт Поспелова & $\begin{array}{c}2 \text { ч с учё- } \\
\text { том до- } \\
\text { роги }\end{array}$ & $\begin{array}{l}600 \text { руб. } \\
\text { (сопровож- } \\
\text { дающий } \\
\text { бесплатно) }\end{array}$ \\
\hline $\begin{array}{l}\text { Музей- } \\
\text { заповедник } \\
\text { «Владивосток- } \\
\text { ская крепость» }\end{array}$ & $\begin{array}{l}\text { Обзорная автобусная } \\
\text { экскурсия «Время } \\
\text { крепости» }\end{array}$ & Форт Поспелова & 3 ч & $\begin{array}{l}\text { Полный - } \\
600 \text { руб., } \\
\text { льготный - } \\
400 \text { руб. }\end{array}$ \\
\hline $\begin{array}{l}\text { Музей- } \\
\text { заповедник } \\
\text { «Владивосток- } \\
\text { ская крепость» }\end{array}$ & $\begin{array}{l}\text { Обзорная автобусная } \\
\text { экскурсия «Город- } \\
\text { крепость» }\end{array}$ & $\begin{array}{l}\text { Дома инженеров - } \\
\text { Фёдорова, Шошина, } \\
\text { Маака, а также зда- } \\
\text { ния крепостного } \\
\text { штаба, офицерского } \\
\text { собрания, казармы }\end{array}$ & 3 ч & $\begin{array}{l}\text { Полный - } \\
800 \text { руб., } \\
\text { льготный - } \\
600 \text { руб. }\end{array}$ \\
\hline $\begin{array}{l}\text { Музей- } \\
\text { заповедник } \\
\text { «Владивосток- } \\
\text { ская крепость» }\end{array}$ & $\begin{array}{l}\text { Обзорная автобусная } \\
\text { экскурсия «Прикрывая } \\
\text { Босфор» }\end{array}$ & $\begin{array}{l}\text { Форт Поспелова, } \\
\text { батарея № } 375 \text { Но- } \\
\text { восильцевская }\end{array}$ & 3 ч & $\begin{array}{l}\text { Полный - } \\
600 \text { руб., } \\
\text { льготный - } \\
400 \text { руб. }\end{array}$ \\
\hline
\end{tabular}

Несмотря на то, что фортификация Владивостока практически полностью доступна для самостоятельного туристского осмотра, маршруты и предлагаемые туры пользуются особым спросом со стороны молодых людей. Во-первых, это может быть связано с тем, что большинство экскурсий охватывают подземелье крепости, а молодые люди особенно ориентированы на его осмотр и исследование, потому что маршруты, проложенные по тёмным потернам, являются чуть 
А.Ю. Кононов, К.А. Мальцева. Военно-исторический туризм как перспективное направление...

ли не главной приключенческой составляющей тура. Во-вторых, в большинстве случаев из-за транспортной недоступности добраться до крепостных объектов можно только пешком, что соответствует стремлению молодёжи к активности.

Анализируя таблицу, можно отметить, что практически все сооружения крепости, доступные к осмотру и посещению, используются в качестве объектов экскурсионного показа. Исключение составляют лишь те форты, доступ к которым запрещён либо затруднителен с транспортной точки зрения. В настоящее время наиболее популярным у молодежи объектом крепости является форт Поспелова, так как представляет собой несколько локальное, по сравнению с другими объектами, сооружение, которое не располагает опасными подземными участками. Вместе с тем форт Поспелова находится в транспортной доступности, позволяющей беспроблемно добираться до объекта даже на легковом автомобиле.

На рынке туризма представлены многодневные военно-исторические туры (табл. 5) [26, 27].

Таблица 5

Военно-исторические туры в Приморский край

\begin{tabular}{|l|l|c|c|}
\hline \multicolumn{1}{|c|}{ Название } & \multicolumn{1}{|c|}{ Организатор } & Дни & Стоимость, руб. \\
\hline $\begin{array}{l}\text { Военно-историческая экскур- } \\
\text { сия и музей автомотостарины }\end{array}$ & Дальинфотур & 3 & 7800 \\
\hline Знакомство с Владивостоком & $\begin{array}{l}\text { Дальневосточный центр } \\
\text { туризма }\end{array}$ & 2 & 8700 \\
\hline $\begin{array}{l}\text { Владивосток - город военный, } \\
\text { город морской! }\end{array}$ & Востокинтур & 3 & 10150 \\
\hline $\begin{array}{l}\text { Владивосток } \\
\text { Россия, Владивосток }\end{array}$ & Путёвочка & 5 & 14200 \\
\hline Четыре истории Владивостока & Борьшая страна & 4 & 15200 \\
\hline Владивосток - город-крепость & Нисса-Тур & 5 & 46800 \\
\hline
\end{tabular}

По сравнению с Центральным федеральным округом у местных туроператоров можно отметить значительно меньшее количество предложений и более ярко выраженную ценовую сегментацию. В то же время туры со средней продолжительностью 3 дня по стоимости соотносятся с турами, представленными в табл. 2, и являются привлекательными для молодежи.

В настоящее время Владивостокская крепость стремительно и уверенно развивается как объект военно-исторического туризма, несмотря на наличие некоторых существенных трудностей. Прежде всего, главной проблемой крепости является её разрушение. Морской климат, постоянство солёных ветров и безжа- 
лостный вандализм не прошли бесследно для крепостных объектов, многие из которых под влиянием внешних факторов пришлось признать разрушенными.

Нельзя не отметить и расположение крепости: большая часть фортов занимает господствующие вершины, представленные сопками, что затрудняет подъезд к ним. Транспортная доступность в данном случае становится значительно ограниченной в силу плохого состояния дорог или вовсе их отсутствия. Вместе с тем единственные тропы, пролегающие через лесную местность, поросшую жёстким кустарником, часто являются единственной возможностью маршрута, что сокращает способы массового посещения крепости.

Стоит отметить, что и сами сооружения признаются довольно опасными объектами, особенно их подземные составляющие - люки, лестницы, колодцы, спуски, затопленные и разрушенные участки. Вследствие этого туристские объекты ориентированы преимущественно на население среднего возраста.

На примере главенствующих объектов Владивостокской крепости можно выделить и детально конкретизировать основные проблемы, препятствующие успешному развитию военно-исторического туризма в Приморском крае (рис. 4).

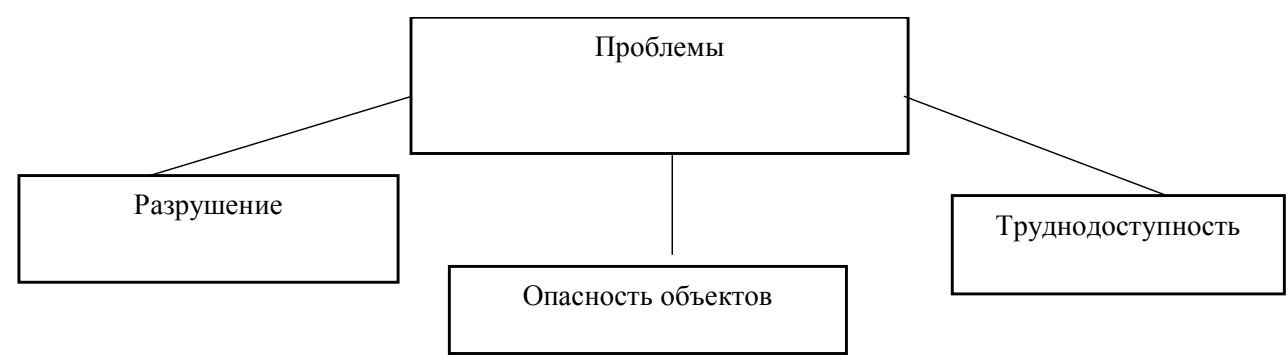

Рис. 4. Проблемы развития военно-исторического туризма

Для решения отмеченных проблем потребуются определенные меры, систематизированные в табл. 6.

Таблица 6

\section{Меры для дальнейшего развития военно-исторического туризма в Приморском крае}

\begin{tabular}{|l|l|l|}
\hline \multicolumn{1}{|c|}{ Проблема } & \multicolumn{1}{|c|}{ Мера } & \multicolumn{1}{|c|}{ Эффект } \\
\cline { 1 - 2 } $\begin{array}{l}\text { Труднодоступность } \\
\text { объектов }\end{array}$ & $\begin{array}{l}\text { Развитие транспортной инфраструктуры, } \\
\text { возможностей использования специаль- } \\
\text { ного проходимого транспорта }\end{array}$ & $\begin{array}{l}\text { Сокращение транспорт- } \\
\text { ных издержек; } \\
\text { возможность формировать } \\
\text { более безопасный и более } \\
\text { разнообразный продукт }\end{array}$ \\
\cline { 1 - 2 } Разрушение объектов & $\begin{array}{l}\text { Частичное возможное восстановление } \\
\text { объектов }\end{array}$ & $\begin{array}{l}\text { Установка ограждений, специальных } \\
\text { предупреждающих знаков, внедрение } \\
\text { систем контроля за безопасностью по- } \\
\text { сещающих }\end{array}$ \\
\hline
\end{tabular}


А. Ю. Кононов, К.А. Мальцева. Военно-исторический туризм как перспективное направление...

При этом помимо экскурсионных маршрутов объекты Владивостокской крепости в настоящее время используются в качестве тематических фестивальных локаций, организацией которых занимается музей-заповедник.

Успешно реализуемым проектом по привлечению целевой аудитории, в том числе и молодёжной, может считаться ежегодный фестиваль «Музыкальный пикник», проводимый на форте Поспелова, форте № 1 и на территории 13-го порохового погреба. Согласно статистическим данным музея-заповедника «Владивостокская крепость» в 2019 году фестиваль посетили 3000 человек. В 2020 году, несмотря на нестабильную ситуацию, вызванную пандемией, участниками фестиваля стали 5000 человек. Однако в 2021 году их количество уменьшилось до 450 человек - фестиваль не был организован в полном масштабе из-за непогоды. Тем не менее традиционно большой процент посещаемых составляют люди от 18 до 35 лет.

Способом популяризации Владивостокской крепости также можно считать не так давно организованный фестиваль «День крепости», локализировавшийся на территории форта № 1 и охвативший почти 3000 человек.

В рамках фестивальных мероприятий проводятся образовательные встречи, исторические лектории, посвящённые вехам Владивостокской фортификации, организуются интерактивные зоны, преимущественно ориентированные на молодёжную целевую аудиторию.

\section{Выводы}

Таким образом, военно-исторический туризм в России успешно развивается благодаря богатому историческому наследию страны. Памятники военноинженерной направленности в настоящее время стали вызывать активный интерес у туристов. При этом развитие военно-исторического туризма рассматривается как приоритетное направление туристской отрасли в стране: на федеральном и региональном уровне проводятся мероприятия по восстановлению и адаптации использования объектов туризма военного наследия в туристических целях. Бывшие комплексы крепостей, мемориалов, иных сооружений реставрируются, музеефицируются и используются в качестве популярных туристских объектов; растет количество соответствующих фестивалей и мероприятий.

Вместе с тем военно-исторический туризм - то направление, которое может быть интересно молодёжи из-за возможности удовлетворения их потребностей в экспериментальных приключенческих поездках, а также из-за возможности интерактивного межкультурного диалога, познания мира. При этом в ходе исследования были систематизированы особенности развития военно-исторического туризма в Приморском крае в контексте его востребованности у молодежи.

Анализ разработанных региональных маршрутов, раскрывающих тему знакомства с военным наследием, выявил основные объекты показа, абсолютное большинство из которых приходится на Владивостокскую крепость.

В ходе исследования также был проведен анализ сформированных туров и экскурсий военно-исторической тематики, составлен комплексный авторский реестр объектов показа, фиксирующий их текущее состояние и востребованность. Отдельное внимание было уделено событийной составляющей военно- 
исторического туризма; были предложены меры для дальнейшего развития военно-исторического туризма в Приморском крае.

1. Стратегия развития туризма на период до 2035 года. - Текст: электронный // Федеральное агентство по туризму: [сайт]. - URL: https://tourism.gov.ru/upload/iblock/298/ Стратегия\%20развития\%20туризма\%20на\%20период\%20до\%202035\%20года.pdf (дата обращения: 13.11.2021).

2. Послание Президента Федеральному собранию. - Текст: электронный // Президент России: [сайт]. - URL: http://www.kremlin.ru/events/president/transcripts/messages/65418 (дата обращения: 13.11.2021).

3. Taleb Rifai Global Report on the Power of Youth Travel 2016. - Текст: электронный // UNWTO: [сайт]. - URL: https:// https://www.eunwto.org/doi/pdf/10.18111/ 9789284414574 / (дата обращения: 12.11.2021).

4. Facts and Stats. - Текст: электронный // WYSE Travel Confederation: [сайт]. - URL: https://www.wysetc.org/about-us/facts-and-stats/ (дата обращения: 12.11.2021).

5. Федеральный закон «Об основах туристской деятельности в Российской Федерации» от 24.11.1996 № 132-Ф3 (ред. от 02.07.2021). - Текст: электронный // Консультант Плюс: [сайт]. - URL: http://www.consultant.ru/document/cons_doc_ LAW_ 12462/bb9e97fad9d14ac66df4b6e67c453d1be3b77b4c/ (дата обращения: 13.11.2021).

6. Писаревский Е.Л. Основы туризма. - Текст: электронный // Федеральное агентство по туризму: [сайт]. - URL: https://tourism.gov.ru/data/File/news_file/ 2014/PISAREVSKIY_Osnovi\%20turizma.pdf (дата обращения: 13.11.2021).

7. Соломина И. Ю., Малышева Д. Д. К вопросу об организации военно-исторического туризма в Севастополе // Таврические студии: культурология. - 2019. - С. 19-28.

8. Голикова Е.С. Военно-исторический туризм: динамика туристского потока в Севастопольском регионе // Студенческая наука. - 2017. - С. 84-87.

9. Шаваринский Б. М., Зотов И. В. Роль и место патриотического воспитания как важнейшего направления патриотического воспитания молодёжи в современных условиях // Воспитание в современной образовательной среде. - 2015. - С. 83-92.

10. Левин В.И. Военно-исторический туризм как один из способов патриотического воспитания // Наука и культура России. - 2017. - С. 364, 365.

11. Мещерякова Я. В., Кузибецкая Г. В. Патриотическое воспитание современной молодёжи как условие развития современного общества: опыт взаимодействия «Волгоград - Севастополь» // Потемкинский форум. - 2020. - С. 279-283.

12. Федеральная целевая программа «Развитие внутреннего и въездного туризма в Российской Федерации (2011-2018)». - Текст: электронный // Федеральное агентство по туризму: [сайт]. - URL: https://tourism.gov.ru/contents/deyatelnost/programmy-iproekty/gosudarstvennye-programmy-realizovannye-rosturizmom-do-2020-

goda/federalnaya-tselevaya-programma-razvitie-vnutrennego-i-vezdnogo-turizma-vrossiyskoy-federatsii-2011-2018-gody-/ е (дата обращения: 12.11.2021).

13. Особенности военно-исторического туризма: - Текст: электронный // Разработка и обоснование туристского продукта на примере военно-исторического тура: [сайт]. URL: https://privetstudent.com/ (дата обращения: 12.11.2021).

14. Атлас «Военно-исторические маршруты России». - Текст: электронный // Федеральное агентство по туризму: [сайт]. - URL: https://tourism.gov.ru/contents/ deyatelnost/programmy-i-proekty/gosudarstvennye-programmy-realizovannyerosturizmom-do-2020-goda/federalnaya-tselevaya-programma-razvitie-vnutrennego-ivezdnogo-turizma-v-rossiyskoy-federatsii-2011-2018-gody-l e (дата обращения: 12.11.2021). 
А.Ю. Кононов, К.А. Мальцева. Военно-исторический туризм как перспективное направление...

15. Туры военной тематики по России. - Текст: электронный // Наша Россия: [сайт]. URL: http://russianasha.ru/tury-voennaya-tematika (дата обращения: 13.11.2021).

16. Об утверждении Концепции федеральной целевой программы «Развитие внутреннего и въездного туризма в Российской Федерации (2019-2025)». - Текст: электронный // Электронный фонд правовых и нормативно-технических документов: [сайт]. URL: https://docs.cntd.ru/document/557414759 (дата обращения: 13.11.2021).

17. Щур В. В., Сергиенко Ю Ю., Кононов А. Ю. Organizational and Economic Aspects of Military Heritage Tourism in Primorsky Krai // Atlantis Press. - 2020. - C. 2, 3.

18. Гомилевская Г. А. Организационно-экономические аспекты военно-исторического туризма в Приморском крае // Территория новых возможностей. Вестник Владивостокского государственного университета экономики и сервиса. - 2018. - С. 55-72.

19. Владивостокская крепость. - Текст: электронный // Музей-заповедник «Владивостокская крепость»: [сайт]. - URL: https://fortressvl.ru/ (дата обращения: 13.11.2021).

20. Авилов Р. С., Аюшкин Н.Б., Калинин В. И. Владивостокская крепость. Часть 3. Крепость трех измерений. - Владивосток: Дальнаука, 2016. - С. 483-498.

21. Объекты Владивостокской крепости. - Текст: электронный // KFSS: [сайт]. - URL: http://kfss.ru/object/obekty-vladivostokskoy-kreposti/vladivostokskaya-krepost (дата обращения: 12.11.2021).

22. Авилов Р.С., Аюшкин Н.Б., Калинин В.И. Владивостокская крепость. Часть 1. 1860 1905 гг. - Владивосток: Дальнаука, 2013. - С. 9-15.

23. Этапы строительства Владивостокской крепости. - Текст: электронный // Музейзаповедник «Владивостокская крепость»: [сайт]. - URL: https://fortressvl.ru/history/ (дата обращения: 13.11.2021).

24. Сведения из Единого государственного реестра объектов культурного наследия (памятников истории и культуры) народов Российской Федерации. - Текст: электронный // Единый государственный реестр объектов культурного наследия (памятников истории и культуры) народов Российской Федерации: [сайт].- URL: https://opendata.mkrf.ru/opendata/ (дата обращения: 12.11.2021).

25. Виды объектов культурного и исторического наследия. - Текст: электронный // Объекты культурного и исторического наследия Карелии: [сайт].- URL: http://monuments.karelia.ru/ob-ekty-kul-turnogo-nasledija/vidy-ob-ektov-kul-turnogo-iistoricheskogo-nasledija/ (дата обращения: 13.11.2021).

26. Экскурсии Владивостокского диггер-клуба. - Текст: электронный // Владивостокский диггер-клуб: [сайт]. - URL: http://www.vladdig.org/ (дата обращения: 13.11.2021).

27. Экскурсии музея-заповедника «Владивостокская крепость. - Текст: электронный // Музей-заповедник «Владивостокская крепость: [сайт].- URL: https://fortressvl.ru/tours/ (дата обращения: 12.11.2021).

\section{Транслитерация}

1. Strategiya razvitiya turizma na period do 2035 goda. - Tekst: elektronnyj // Federal'noe agentstvo po turizmu: [sajt]. https://tourism.gov.ru/upload/iblock/298/Strategiya\%20razvitiya\%20turizma\%20na\%20peri od\%20do\%202035\%20goda.pdf (data obrashcheniya: 13.11.2021).

2. Poslanie Prezidenta Federal'nomu sobraniyu. - Tekst: elektronnyj // Prezident Rossii: [sajt]. - URL: http://www.kremlin.ru/events/president/transcripts/messages/65418 (data obrashcheniya: 13.11.2021).

3. Taleb Rifai Global Report on the Power of Youth Travel 2016. - Tekst: elektronnyj // $\begin{array}{lllll}\text { UNWTO: } & \text { [sajt]. } & - & \text { URL: } & \text { https:// }\end{array}$ 
https://www.eunwto.org/doi/pdf/10.18111/9789284414574/ (data obrashcheniya: 12.11.2021).

4. Facts and Stats. - Tekst: elektronnyj // WYSE Travel Confederation: [sajt]. - URL: https://www.wysetc.org/about-us/facts-and-stats/ (data obrashcheniya: 12.11.2021).

5. Federal'nyj zakon «Ob osnovah turistskoj deyatel'nosti v Rossijskoj Federacii" ot 24.11.1996 № 132-FZ (red. ot 02.07.2021). - Tekst: elektronnyj // Konsul'tantPlyus: [sajt]. - URL: http://www.consultant.ru/document/cons_doc_LAW_12462/bb9e97fad9d14ac66df4b6e67c4 53d1be3b77b4c/ (data obrashcheniya: 13.11.2021).

6. Pisarevskij E.L. Osnovy turizma. - Tekst: elektronnyj // Federal'noe agentstvo po turizmu: [sajt]. - URL: https://tourism.gov.ru/data/File/ news_file/2014/ PISAREVSKIY_Osnovi\%20turizma.pdf (data obrashcheniya: 13.11.2021).

7. Solomina I.YU., Malysheva D.D. K voprosu ob organizacii voenno-istoricheskogo turizma v Sevastopole // Tavricheskie studii: kul'turologiya. - 2019. - S. 19-28.

8. Golikova E.S. Voenno-istoricheskij turizm: dinamika turistskogo potoka v Sevastopol'skom regione // Studencheskaya nauka. - 2017. - S. 84-87.

9. SHavarinskij B.M., Zotov I.V. Rol' i mesto patrioticheskogo vospitaniya kak vazhnejshego napravleniya pat-rioticheskogo vospitaniya molodyozhi v sovremennyh usloviyah // Vospitanie v sovremennoj obrazovatel'noj srede. -2015 . - S. 83-92.

10. Levin V.I. Voenno-istoricheskij turizm kak odin iz sposobov patrioticheskogo vospitaniya // Nauka i kul'tura Rossii. - 2017. - S. 364-365.

11. Meshcheryakova Ya.V., Kuzibeckaya G.V. Patrioticheskoe vospitanie sovremennoj molodyozhi kak uslovie razvi-tiya sovremennogo obshchestva: opyt vzaimodejstviya "Volgograd - Sevastopol'» // Potemkinskij forum. - 2020. - S. 279-283.

12. Federal'naya celevaya programma «Razvitie vnutrennego i v"ezdnogo turizma v Rossijskoj Federacii (2011-2018)». - Tekst: elektronnyj // Federal'noe agentstvo po turizmu: [sajt]. URL: https://tourism.gov.ru/contents/deyatelnost/programmy-i-proekty/gosudarstvennyeprogrammy-realizovannye-rosturizmom-do-2020-goda/federalnaya-tselevaya-programmarazvitie-vnutrennego-i-vezdnogo-turizma-v-rossiyskoy-federatsii-2011-2018-gody-/ e (data obrashcheniya: 12.11.2021).

13. Osobennosti voenno-istoricheskogo turizma: - Tekst: elektronnyj // Razrabotka i obosnovanie turistsko-go produkta na primere voenno-istoricheskogo tura: [sajt]. - URL: https://privetstudent.com/ (data obrashcheniya: 12.11.2021).

14. Atlas «Voenno-istoricheskie marshruty Rossii». - Tekst: elektronnyj // Federal'noe agentstvo po tu-rizmu: [sajt]. - URL: https://tourism.gov.ru/contents/deyatelnost/programmy-iproekty/gosudarstvennye-programmy-realizovannye-rosturizmom-do-2020goda/federalnaya-tselevaya-programma-razvitie-vnutrennego-i-vezdnogo-turizma-vrossiyskoy-federatsii-2011-2018-gody-/ e (data obrashcheniya: 12.11.2021).

15. Tury voennoj tematiki po Rossii. - Tekst: elektronnyj // Nasha Rossiya: [sajt]. - URL: http://russianasha.ru/tury-voennaya-tematika (data obrashcheniya: 13.11.2021).

16. Ob utverzhdenii Koncepcii federal'noj celevoj programmy «Razvitie vnutrennego i v"ezdnogo turizma v Rossijskoj Federacii (2019-2025)". - Tekst: elektronnyj // Elektronnyj fond pravovyh i normativno-tekhnicheskih dokumentov: [sajt]. - URL: https://docs.cntd.ru/document/557414759 (data obrashcheniya: 13.11.2021).

17. Shchur V.V., Sergienko Yu.Yu., Kononov A.Yu. Organizational and Economic Aspects of Military Heritage Tourism in Primorsky Krai // Atlantis Press. - 2020. - S. 2, 3.

18. Gomilevskaya G.A. Organizacionno-ekonomicheskie aspekty voenno-istoricheskogo turizma v Primorskom krae // Territoriya novyh vozmozhnostej. Vestnik Vladivostokskogo gosudarstvennogo universiteta ekonomiki i servisa. - 2018. - S. 55-72. 
19. Vladivostokskaya krepost'. - Tekst: elektronnyj // Muzej-zapovednik «Vladivostokskaya krepost'»: [sajt]. - URL: https://fortressvl.ru/ (data obrashcheniya: 13.11.2021).

20. Avilov R.S., Ayushkin N.B., Kalinin V.I. Vladivostokskaya krepost'. CHast' 3. Krepost' trekh izmerenij. - Vladivostok: Dal'nauka, 2016. - S. 483-498.

21. Ob"ekty Vladivostokskoj kreposti. - Tekst: elektronnyj // KFSS: [sajt]. - URL: http://kfss.ru/object/obekty-vladivostokskoy-kreposti/vladivostokskaya-krepost (data obrashcheniya: 12.11.2021).

22. Avilov R.S., Ayushkin N.B., Kalinin V.I. Vladivostokskaya krepost'. CHast' 1. 1860-1905 gg. - Vladivostok: Dal'nauka, 2013. - S. 9-15.

23. Etapy stroitel'stva Vladivostokskoj kreposti. - Tekst: elektronnyj // Muzej-zapovednik «Vladivostokskaya krepost'»: [sajt]. - URL: https://fortressvl.ru/history/ (data obrashcheniya: 13.11.2021).

24. Svedeniya iz Edinogo gosudarstvennogo reestra ob"ektov kul'turnogo naslediya (pamyatnikov istorii i kul'tury) narodov Rossijskoj Federacii. - Tekst: elektronnyj // Edinyj gosudarstvennyj reestr ob"ektov kul'turnogo naslediya (pamyatnikov istorii i kul'tury) narodov Rossijskoj Federacii: [sajt]. - URL: https://opendata.mkrf.ru/opendata/ (data obrashcheniya: 12.11.2021).

25. Vidy ob"ektov kul'turnogo i istoricheskogo naslediya. - Tekst: elektronnyj // Ob"ekty kul'turnogo i istoricheskogo naslediya Karelii: [sajt]. - URL: http://monuments.karelia.ru/ob-ekty-kul-turnogo-nasledija/vidy-ob-ektov-kul-turnogo-iistoricheskogo-nasledija/ (data obrashcheniya: 13.11.2021).

26. Ekskursii Vladivostokskogo digger-kluba. - Tekst: elektronnyj // Vladivostokskij diggerklub: [sajt]. - URL: http://www.vladdig.org/ (data obrashcheniya: 13.11.2021).

27. Ekskursii muzeya-zapovednika «Vladivostokskaya krepost'. - Tekst: elektronnyj // Muzejzapovednik «Vladivostokskaya krepost': [sajt]. - URL: https://fortressvl.ru/tours/ (data obrashcheniya: 12.11.2021).

() А.Ю. Кононов, 2021

(ㄱ) К. А. Мальцева, 2021

Для цитирования: Кононов А. Ю., Мальцева К. А. Военно-исторический туризм как перспективное направление молодежного туризма в Приморском крае // Территория новых возможностей. Вестник Владивостокского государственного университета экономики и сервиса. - 2021. - Т. 13, № 4. - С. 50-71.

For citation: Kononov A.Yu., Maltseva K.A. Military tourism as a promising direction of youth tourism in Primorsky Krai, The Territory of New Opportunities. The Herald of Vladivostok State University of Economics and Service, 2021, Vol. 13, № 4, pp. 50-71.

DOI https://doi.org/10.24866/VVSU/2073-3984/2021-4/050-071

Дата поступления: $\quad$ Одобрена после рецензирования: 15.11.2021
Одобрена пос
Принята к публикации: 22.11.2021 